\title{
BEGINNINGS AND DEVELOPMENT OF RUGBY IN SINGAPORE
}

\author{
Govindasamy Balasekaran ${ }^{1}$, Peggy Boey ${ }^{1}$ and Ng Yew Cheo ${ }^{1}$ \\ ${ }^{1}$ National Institute of Education, Nanyang Technological University, Singapore
}

UDK 793/799:796.333(592.3)

\section{SUMMARY}

In those early days, some sports were played as a variation of another. Rugby was one of the sports which was played as a variation of football. Codification of rugby rules took place only in the middle 1800 century and hence, participants of rugby games were a mixture of players from other sports such as tennis and cricket. Also, there was no formal rugby association or players with Singapore representation. The players that played for Singapore were members of the SCC and employees of the BEIC. Back then, they competed in tournaments against the Malayan states and other teams.

Key words: rugby, games, ball.

\section{Corresponding author}

Govindasamy Balasekaran

govindasamy.b@nie.edu.sg

\section{INTRODUCTION}

In the 1800s, when sports such as football, cricket, horse racing, yachting, swimming, lawn tennis, polo, soccer, field hockey and cricket were introduced into Singapore by the British East India Company (BEIC), it functioned only as a leisure activity for the British (Oon, 1984 \& Hourton, 2012). Locals and immigrants spent most of their hours working, leaving only a small fraction of time for traditional cultural activities (Hourton, 2007). Often, they would participate as spectators to deviate themselves away from the mundane and hard labour lifestyle (Aplin, 2002). Even after the emergence of middle-class Chinese, participation in sports was still relatively low. It was most likely due to the importance of engineering the 
economic success of a young nation where building up the basic economy growth was a key factor. In the midst of everything, the second oldest sports club, the Singapore Cricket Club (SCC) was established in 1852 "to serve as an elite colonial sports club to a multi-racial club catering to the sporting and social needs of the Singapore community" (Tan, 2016). Gradually as Singapore's economy grew, more sports clubs sprouted but were created to serve only specific racial communities (Sport Singapore, 2017). This marked the era of an increase in sports participation by the locals and having support by their respective sports club.

In those early days, some sports were played as a variation of another. Rugby was one of the sports which was played as a variation of football. Codification of rugby rules took place only in the middle 1800 century and hence, participants of rugby games were a mixture of players from other sports such as tennis and cricket. Also, there was no formal rugby association or players with Singapore representation. The players that played for Singapore were members of the SCC and employees of the BEIC. Back then, they competed in tournaments against the Malayan states and other teams.

\section{RUGBY AS AN AMATEUR SPORT IN SINGAPORE}

Before the Singapore Rugby Union (SRU) was formed in 1948, rugby in Singapore was formerly known as rugby football and its rules were only established in the middle century (Godfrey, 2018). Only in the 1800s, the rugby union was entrenched under a separate code (Godfrey, 2018). Previously, players who participated in rugby competitions were members of the SCC who played cricket and were also football players. As the sport grew in popularity, many teams emerged from clubs or military forces. The British servicemen from the air force, navy and army competed for their own teams respectively but together, they were identified as the Joint Services (Godfrey, 2018).

The first official Singapore rugby team was named - All Blues that comprised of expatriate civilian members. They represented Singapore till 1972 in annual games against various Malaysia states (Johor, Malacca, Selangor and Perak) for the All Blues Cup, the Agong Cup interstate competition and the Malaya Cup tournament (Godfrey, 2018). In 1950s, the Singapore Civilians team was formed, and members were either local or expatriates who were strictly non-military personals (SRU, 2020 \& Godfrey, 2018). Both teams often combined to represent Singapore for all competitions until 1965 (SRU, 2020 \& Godfrey, 2018). Attributing to the colonization period, the ratio between expatriates to locals in the rugby teams were greater in the former and any local selected for the team was prestigious. Between 1960s and 1970s, three other teams also dominated the rugby scene - the Blacks Rugby Football Club, Police Sports Association and the Singapore Armed Forces Sports Association (Godfrey, 2018). 


\section{RUGBY AFTER INDEPENDENCE}

After Singapore's independence in 1965, the Selangor Rugby Union unsuccessfully called for Singapore's team to be excluded from the 1966 Malaya Cup (Little, 2013). Unaffected, Singapore Rugby entered the golden era in the 1970s. A Singapore team was formed in 1971, that played against a famous England Team at the Jalan Besar stadium (SRU, 2020). Two landmark occasions occurred in 1972; the changeover of SRU's presidency and formation of a national team. The first president of SRU, Dennis Bindon, was replaced by Niaz Mohamed Shah, a member of the All Blues team. Thereafter, the local rugby players improved in their game play and skills. Concurrently, Niaz sent an all-Asian team for international competitions, led by our first Asian Captain, Leow Kim Liat. The all-Asian team put on a good fight in the Asian Rugby Football Union Championships and earned $4^{\text {th }}$ place after beating the Asean Kingpins - Japan, South Korea and Thailand (Godfrey, 2018). Moreover, rugby in schools and clubs started to progress as they were hiring good coaches and developing good players, which resulted in emerging young Singaporean rugby players. (Godfrey, 2018).

As each country's rugby union can be easily identified by their emblems, the first logo adopted by the SRU was an image of a lion under a coconut tree (Figure 1). Natahar Bava, former national rugby player and a national coach in the 1970s, suggested for a change in the emblem's design; one that would inspire his national players. The SRU logo was then petitioned to be redesigned and the final emblem is adopted from our national orchid flower, Vanda Miss Joaquim (Figure 2). It depicts vibrancy, hardiness and resilience; qualities which Natahar Bava believes a player should possess.

Between 1973 to 1976, Niaz reshuffled the local team for various tournaments. Making up for the physiological differences and poor attendance due to National Service, Naiz enforced tough trainings and often fielded the team against stronger teams such as New Zealand Forces and the Australian Forces North (Godfrey, 2018). Hence, the first national rugby team had their first opportunity to compete in the 1975 Southeast Asian Peninsular Games (SEAP Games). In the same year, the first defense minister, Dr Goh Keng Swee, introduced the sport to Singapore's military, Singapore Armed Forces (SAF). He saw rugby as a sport that could build hardiness, teamwork and strategy skills into new recruits and regulars.

SRU went through another change in presidency in 1977, which was handed over to Cashin Howard. He also shared the same belief in fielding a team of locals for international and local games despite the disapprovals and negative comments. Howard extended Natahar Bava as the national team's coach. They both shared identical ideologies in training methods, player recruitment and future strategies for the team, making the two a perfect duo for leading the national team to greater achievements. 


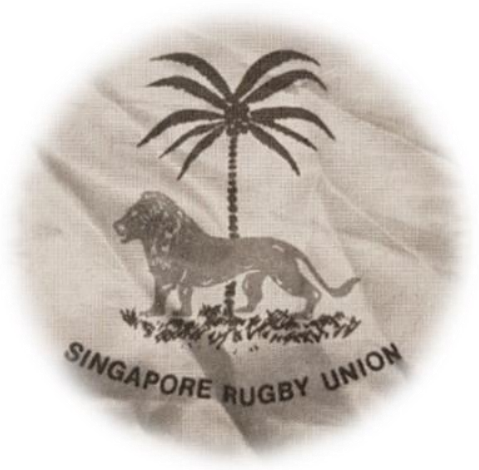

Figure 1. First emblem of Singapore Rugby Union

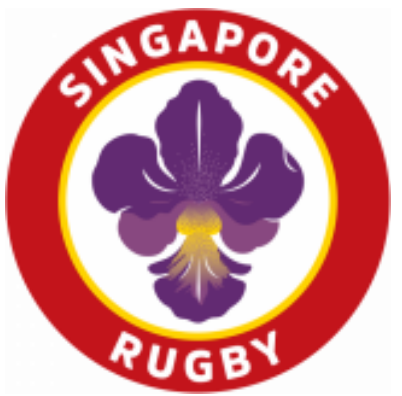

Figure 2. Current emblem of Singapore Rugby Union

The national team had the honour of competing again in the 1977 SEAP Games in Kuala Lumpur. Due to the short notice, the national team only knew of the confirmation months prior to the games, as compared to their competitors who would have at least a year to condition and train for the biennial game (Godfrey, 2018). In addition, the national team was made up of players who were working adults and club commitments which meant training as a team was insufficient at that point of time. Despite the obstacles faced, they put on a good fight and emerged as silver medalists. Thereafter, the SEAP Games was renamed Southeast Asia Games (SEA Games). In the subsequent SEA Games, with rising competition and increasing talents from other countries, Singapore's national team still managed the bronze medal in 2007 and 2015. The second greatest win was in the 1978 Asian Rugby Tournament. They attained the third place, behind powerhouses - Japan and South Korea (SRU, 2020). That glorious victory in 1978 earned them three awards presented by the Singapore National Olympic Council (SNOC) - "Team of the Year", "Coach of the Year" (Natahar Bava) and "Sportsman of the Year" (Captain Song Koon Poh).

\section{FINANCIAL CONSTRAINTS}

Despite the smooth administrative management by Dennis, first president of SRU, Niaz and Cashin, financial issues remained a primary concern and fundraising dinners were often organized, at times jointly organized with SCC. In 1974 , the rugby team raised a total of eight thousand dollars to send the national rugby team to Sri Lanka for the Asian Rugby Tournament (SRU, 2020).

As an emerging sport, financial support was minimal from the Singapore Sports Council (SSC) and players often had to pay for their own games. SRU 
worked to be self-sufficient and managed to secure corporate sponsors over the years. Local sponsors such as the Sports Equipment Far East Pte Ltd, Umbro and Gola helped sponsor the team in terms of attire, equipment and kit for the team.

\section{MAJOR REORGANIZATION IN THE SINGAPORE RUGBY UNION}

In 1995, the Singapore Rugby Union reorganized their administrative through the employment of their first Chief Executive Officer, Peter Randell, who then further employed four developmental officers. At that point, SRU was ranked last in the Asia Rugby standings and had only 10 schools playing locally. Under Randell's leadership, SRU's vision and mission were put in place (Figure 3) (SRU, 2020). His primary concern was to increase the number of rugby-playing schools and become the top rugby team in SEA. There and then, rugby clinics were introduced to rugby schools by local clubs - Bedok Kings, Northern Knights, Lion Red, Blacks and Wanderers. Rugby was propagated through a modified game called 'Singa-rugby'. These clinics were held over the weekends and were sponsored by Prudential Insurance. The number of schools that played rugby greatly increased to 100 in 1998, which showed the prowess of the weekend clinics and rugby programs conducted specially for primary schools. The secondary schools were introduced to Touch Rugby in 1996. The prideful year also earned the national team $5^{\text {th }}$ overall in Asia and $1^{\text {st }}$ in the Division 2 competition. With the growing introduction of rugby to many schools, the first Singapore Press Holdings Touch Rugby Carnival garnered more than 100 teams that registered for the event.

OUR VISION

"INSPIRING OUR COMMUNITY IN UNION"

OUR MISSION

"We inspire our community to excellence with good governance, effective leadership and active engagement"

OUR CORE VALUES

PASSION UNITY RESPECT

Figure 3. Vision, mission and core values of Singapore Rugby Union

In the same year, minor reorganizations took place for the team. The national team disbanded, and trials were conducted for the players to qualify for the 1995 SEA games. Moreover, two more developmental officers were appointed, and a head coach was employed for the games. Finances were required to support the 
development program for players; hence fund-raising events were conducted with one dinner organised in conjunction with SCC. As influence from the sport expanded, major sponsors came on board (e.g. 7-Eleven, Coca-Cola, Prudential and Canterbury). Canterbury became the official apparel sponsor of SRU.

1997, four additional sponsors joined to support SRU, Standard Chartered, M1, Adidas and Anchor Beer. By then, the national team was distinctively identified as the Anchor Reds. In that same year, the team played in the old Singapore's National Stadium for the Standard Chartered Cup against China and won 33-3. After 10 years, the woman's team clinched their ever first win against Malaysia in the Hong Kong Sevens. The first men's win for the Hong Kong Sevens was proudly achieved in 2002. The Under 18 team represented Singapore in the Standard Chartered Under 18 Triangular and defeated both teams from Hong Kong and Thailand. The Young Team Merit Award was awarded to them for their outstanding performance. Additionally, SRU partnered the New Zealand Singapore Business Council to create the Rising Start Award that recognized, rewarded and motivated potential rugby star players.

Singapore hosted a few rugby games in 1998, namely the Standard Chartered Asian Rugby Championship and SPH Touch Rugby tournament that were held at the Ngee Ann City Civic Plaza and the old Singapore National Stadium respectively. An SRU exhibition was also held at the civic plaza in conjunction with the rugby championship.

In the following year, 1999, SRU had two new sponsors - Citizen Watch Company and Fuji Xerox. Besides being an apparel sponsor, Adidas also included footwear sponsorship for SRU. During this period, Singapore's rugby national team was one of the three countries in the world whose jerseys were produced by Adidas. By the 2000s, rugby was seen as more spirited and manly than football in Singapore (Goh, 2014).

\section{MAJOR COMPETITIONS AFTER REORGANIZATION OF SRU}

Rugby among the women also grew increasingly popular, hence both the male and female national teams started to compete more frequently at international standards (Asia Rugby and SEA games) (Table 1).

Table 1. Major Competitions' Achievements from 2000

\begin{tabular}{|l|l|}
\hline Year & Competitions \\
\hline 2000 & SRU maintained the Division 2 title in the Asian Championship. \\
\hline \multirow{2}{*}{2002} & Men's team lost Asian Rugby Championship Division Two Title. \\
\cline { 2 - 2 } & Men's sevens team beat Japan coming in Champions in the Hong Kong Sevens. \\
\hline
\end{tabular}




\begin{tabular}{|c|c|}
\hline \multirow[t]{2}{*}{2003} & $\begin{array}{l}\text { The women's sevens finished } 2^{\text {nd }} \text { in the Asian Women's Sevens in Kazakhstan, } \\
\text { which also earned them the SNOC Award. }\end{array}$ \\
\hline & $\begin{array}{l}\text { IRB sevens Singapore was canceled due to the SARS virus but was brought } \\
\text { back in the following year. }\end{array}$ \\
\hline \multirow[t]{2}{*}{2004} & $\begin{array}{l}\text { Men's } 15 \text { team fought and defeated Arabian Gulf and Thailand to regain their } \\
\text { Division } 2 \text { title. }\end{array}$ \\
\hline & Women's team lost to Japan in the semi-finals. \\
\hline 2005 & Men's team competed in the RWC qualifiers but did not advance to next round. \\
\hline 2006 & Women's 15s team competed in the Asian Women's Rugby Championship. \\
\hline 2007 & $\begin{array}{l}\text { In the Korat Games, the men's team won the bronze medal and the women's } \\
\text { team won the silver medal. }\end{array}$ \\
\hline \multirow[t]{2}{*}{2008} & Singapore Rugby Lions - Champions of the ARFU Rugby First Division. \\
\hline & $\begin{array}{l}\text { Won the HSBC trophy (draw against Sri Lanka and one point ahead of Chinese } \\
\text { Taipei). }\end{array}$ \\
\hline 2009 & $\begin{array}{l}\text { Team rose in the IRB World rankings ( } 55^{\text {th }} \text { to } 48^{\text {th }} \text { ranking) }- \text { made it to the } \\
\text { first tier and fixtures against Hong Kong, Japan, Korea and Kazakhstan. }\end{array}$ \\
\hline 2010 & $\begin{array}{l}\text { The women's sevens team competed in the } 2010 \text { Asian Games in Guangzhou, } \\
\text { China and finished } 6^{\text {th }} \text {. }\end{array}$ \\
\hline \multirow[t]{3}{*}{2011} & Men's team finalist in Asia Rugby Championships Division 1. \\
\hline & $\begin{array}{l}\text { U20's men won Kazakhstan }(17-10) \text { that elevated them to Division } 2 \text { of the } \\
\text { Asia Rugby Championships Division } 1 \text {. }\end{array}$ \\
\hline & Women's team crowned Plate Champion in Asia-Pacific Women's Sevens \\
\hline \multirow[t]{3}{*}{2012} & $\begin{array}{l}\text { Men's fifteens team came in } 4^{\text {th }} \text { in the Asian Rugby Division } 1 \text { tournament and } \\
\text { moved to Division } 2 .\end{array}$ \\
\hline & $\begin{array}{l}\text { Women's fifteens team topped the Asian Rugby Division } 2 \text { tournament after } \\
\text { defeating Lao PDR and the Philippines. }\end{array}$ \\
\hline & Women's sevens team came in $6^{\text {th }}$ in the Asian Women's 7s Championships. \\
\hline \multirow[t]{3}{*}{2013} & $\begin{array}{l}\text { Singapore competed in the Tri Nations with Taiwan and Hong Kong 'A' and } \\
\text { came in behind Taiwan. }\end{array}$ \\
\hline & Men's team fought back to regain their status back into Asia Rugby Division 1. \\
\hline & $\begin{array}{l}\text { Women's team competed in the Asian Qualifiers for the Women's Rugby World } \\
\text { Cup. }\end{array}$ \\
\hline \multirow[t]{3}{*}{2014} & $\begin{array}{l}\text { Men's team remained in Division } 1 \text { after new restructuring of Asia Rugby } \\
\text { Championships as they defeated United Arab Emirates } 30-13 \text { in a one-off } \\
\text { promotion match. }\end{array}$ \\
\hline & U19s promoted to ARFU Division 1 after defeating Thailand 22-5. \\
\hline & $\begin{array}{l}\text { National player, Reiner Leong, was invited to play for Asia Pacific Dragons } \\
\text { during the World Cup 10s. }\end{array}$ \\
\hline \multirow[t]{2}{*}{2015} & $\begin{array}{l}\text { Men's team dropped back to Division } 2 \text { in Asia Rugby Championships after } \\
\text { being defeated by Philippines and Kazakstan. }\end{array}$ \\
\hline & $\begin{array}{l}\text { Men's team won the Bronze medal and women's team won the Silver medal at } \\
\text { the } 28^{\text {th }} \text { SEA Games. }\end{array}$ \\
\hline 2016 & Men's and women's team came in $8^{\text {th }}$ and $5^{\text {th }}$ respectively for the Asia Rugby \\
\hline
\end{tabular}




\begin{tabular}{|l|l|}
\hline \multirow{2}{*}{2017} & Sevens Series. \\
\cline { 2 - 2 } & $\begin{array}{l}\text { Men's team had another chance in the Asia Rugby Championship Division 1, } \\
\text { however, they lost out and dropped back to Division 2 once again. }\end{array}$ \\
\cline { 2 - 3 } & Men's sevens team won the Asia Rugby Sevens trophy. \\
\cline { 2 - 3 } & Women's sevens team came in $7^{\text {th }}$ for the Asia Rugby Women's Sevens Series. \\
\cline { 2 - 3 } 2019 & $\begin{array}{l}\text { Men's and women's teams were silver medalists at the 29th SEA Games. } \\
\text { 30th } \text { SEA Games. }\end{array}$ \\
\hline
\end{tabular}

\section{HOSTING RUGBY COMPETITIONS AFTER REORGANIZATION OF SRU}

With rugby becoming more financially and administratively stable in Singapore, SRU went on to host multiple rugby events and competitions to uplift the standards of rugby locally and internationally (Table 2 ).

Table 2. Local and International Rugby Competitions Hosted by Singapore Rugby Union

\begin{tabular}{|c|c|}
\hline Year & Hosting Rugby Competitions \\
\hline 2000 & $\begin{array}{l}\text { SPH Fun Touch Rugby was conducted at the HDB Hub in Toa Payoh as part of } \\
\text { community engagement. }\end{array}$ \\
\hline 2001 & SRU hosted the IRB Sevens Series with Kuala Lumpur. \\
\hline \multirow[t]{2}{*}{2002} & $\begin{array}{l}\text { SRU hosted the IRB Sevens Series with Kuala Lumpur again, which was held at } \\
\text { old National Stadium. }\end{array}$ \\
\hline & SRU hosted the SPH Fun Touch Rugby in Toa Payoh HDB Hub. \\
\hline 2003 & IRB Sevens Singapore was canceled due to SARS. \\
\hline \multirow[t]{2}{*}{2004} & $\begin{array}{l}\text { SRU hosted the annual Asian Women's Ruby Championship in } 2004 \text { with the } \\
\text { finals played at the old Singapore national stadium }\end{array}$ \\
\hline & $\begin{array}{l}\text { SRU hosted the first Beach Rugby Carnival at Sentosa with } 50 \text { participating } \\
\text { teams. }\end{array}$ \\
\hline \multirow[t]{2}{*}{2005} & SRU hosted the IRB Sevens Series. \\
\hline & $\begin{array}{l}\text { SRU hosted the } 2^{\text {nd }} \text { Beach Rugby Carnival at Sentosa with almost } 100 \\
\text { participating teams. }\end{array}$ \\
\hline 2006 & SRU hosted IRB Singapore Sevens in April. \\
\hline 2007 & New CEO, Ian Bremner was appointed. \\
\hline 2008 & $\begin{array}{l}\text { On behalf of Co-curricular Activities Branch (CCAB), SRU hosted the } \\
\text { International and Singapore Athletic Championship (ISSAC) - Rugby } 2008 \\
\text { competition. }\end{array}$ \\
\hline \multirow[t]{2}{*}{2010} & $\begin{array}{l}\text { SRU hosted the Asia Rugby Championships Division } 1 \text { at Yio Chu Kang } \\
\text { stadium. }\end{array}$ \\
\hline & $\begin{array}{l}\text { SRU hosted its } 1^{\text {st }} \text { local sevens series held at Bishan for the national team and } \\
\text { schools to compete. }\end{array}$ \\
\hline
\end{tabular}




\begin{tabular}{|c|c|}
\hline 2012 & $\begin{array}{l}\text { SRU hosted a leg of the HSBC Asian Sevens Series, which was also a qualifier } \\
\text { for then the International Rugby Board's Rugby Sevens Cup, held at Padang. }\end{array}$ \\
\hline 2013 & SRU hosted the Tri Nations series. \\
\hline 2014 & Singapore hosted the World Rugby Meeting for the first time. \\
\hline 2015 & 28 $8^{\text {th }}$ SEA Games was hosted in Singapore. \\
\hline 2016 & $\begin{array}{l}\text { SRU signed a MOU with South Africa, New Zealand, Australia, and Argentina } \\
\text { Rugby (SANZAAR) - The Japan's Sunwolves was the } 18^{\text {th }} \text { Super Rugby } \\
\text { franchise. Therefore, the Sunwolves played } 3 \text { home games at the new } \\
\text { Singapore National stadium. }\end{array}$ \\
\hline \multirow[t]{3}{*}{2017} & SRU played host to Super Rugby match. \\
\hline & SRU hosted the Sevens World Series and secured a 4-year deal. \\
\hline & SRU hosted the $2^{\text {nd }}$ Singapore Sevens edition. \\
\hline 2018 & SRU hosted the HSBC World Rugby Sevens held at the National stadium. \\
\hline \multirow[t]{2}{*}{2019} & SRU hosted the Asian Rugby Sevens Trophy \\
\hline & SRU hosted the Asian Rugby Womens Championships \\
\hline
\end{tabular}

\section{ATTRACTING NEW BLOOD}

In 2002, SRU started collaborations and partnerships with other international universities such as, University of Wales, where 2 students were sent there for a 1year internship as part of their degree curriculum. To improve the rugby clinics and programs that started in 1996, SRU introduced a free Touch and Contact Rugby program in 2006. From the 100 schools playing rugby, there was another increment of 100 participating schools in Singapore in 2006. As part of cultural exchange, 4 under 16 players were selected and sponsored by Standard Chartered to experience the rugby culture in Wales.

The inaugural ISSAC included various age groups for Singapore and International schools with the main objective of strengthening friendship and ties through the game. Secondly, Standard Chartered Bank and SRU launched the first National Rugby Academy offered in Asia. It was helmed by Gene Tong, as manager, to develop rugby elite with full programs for ages 13 to 21 .

Local clubs started to formalize under SRU where new or existing players can choose a club to continue training and competing in national leagues. These clubs are categorized under men (8 clubs), women ( 4 clubs) and junior clubs (10 clubs).

\section{SPONSORS FOR SRU}

The $20^{\text {th }}$ century saw a change and betterment of financial support from big corporations which boosted the sport in local scene. In 2001, M1 moved their 
sponsorship from National Rugby Championships to school series. Furthermore, Victoria Bitter sponsored the 2007 National Rugby Championship.

One of the prominent sponsors, Standard Chartered, renewed its funding to SRU in 2013 with the objective of promoting rugby to local youths through "comprehensive rugby programs including those tailored specifically for the

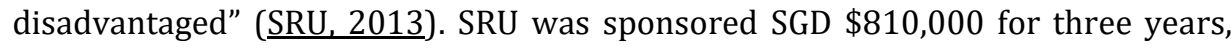
from 2013 to 2016. The partnership with Standard Chartered started since 1997 and it funded the Standard Chartered National Rugby Academy, where clinics and national tournaments were organized. The long-term collaboration was identified to be impactful for SRU to have closer communications and ties with the community and schools. Muhammadiyah Welfare Boys Home and Sport Cares is part of the joint initiative and the program was inclusive of disadvantage youths. With the long-term relationship with Standard Chartered, SRU had developed many rugby talents who had moved on to work with SRU to develop the sport further within and outside the local community. Crediting to their major sponsor, the men's national team are currently ranked the top few in SEA and $3^{\text {rd }}$ for the whole of Asia for the women's team ( $\underline{\mathrm{SRU}, 2013})$.

In addition, Mizuno announced a year extension of footwear sponsorship in 2015 to "30 appointed Mizuno ambassadors ranging from national players, club

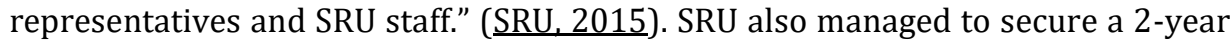
sponsor from the Rhino Rugby for "official and Exclusive Training and Equipment

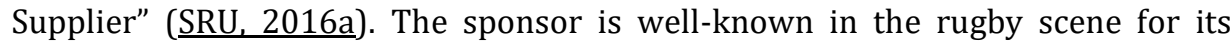
quality equipment which also supports other unions such as Wales, England, South Africa, France, Hong Kong and British \& Irish. It also provided equipment to major competitions such as, the HSBC Singapore World Sevens in 2016 (TODAY,

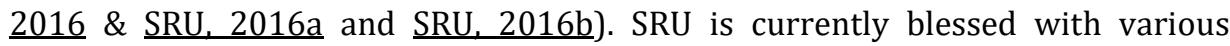
sponsors and partnerships on board to serve the community and internal development of SRU (Figure 4).

\section{SRU's sponsors and partners}

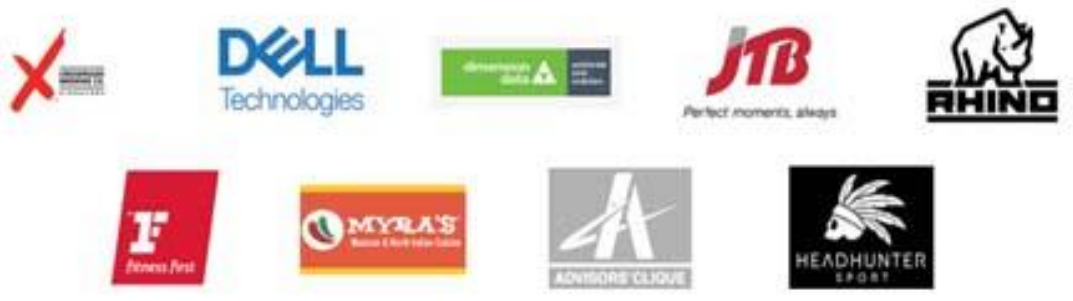

Figure 4. Current SRU's sponsors and partners. 


\section{SINGAPORE RUGBY'S PROGRESSION}

Presently, SRU has 11 strong committee members and 16 dedicated staff running the union and working closely with the commission members, national coaches and team managers. They set yearly targets and compare with the actual results during each Annual General Meeting (AGM), which is recorded in the annual report. They revamp and improve the men's and women's Nationals Leagues to align with the National Teams Commission and Rugby Development Commission. With this new format, more teams are eligible to participate in the National League creating a bigger pool of athletes for talent identification for the national team. This also created a more competitive edge to the stronger teams preparing for the Asia Rugby Division 1 Championship. SRU is also looking into ways to further support clubs with recruiting and developing players for local competitions.

At present, SRU has three Rugby programmes endorsed under the Sports Education Programme (SEP) - "Introduction to Tag Rugby", "Introduction to Touch Rugby" and "Introduction to Rugby", which are promoted in schools who have rugby programmes in the curriculum. SEP is also a collaboration between Sports Singapore (SportsSG) and the Ministry of Education (MOE) that advocates the necessity of sports education, increasing the interest in sports participation in schools and providing more sporting opportunities for students in the primary, secondary and junior colleges.

To keep up and maintain the international standards of rugby, SRU has 13 World Rugby Educators for Coaching, 10 World Rugby Educators for Match Officials, 15 World Rugby Educators for Medical and 3 World Rugby Educators for Strength and Conditioning. These educators are licensed and qualified to conduct workshops in Singapore and Asia.

\section{Conclusion}

The history of rugby came a long way in Singapore, building from scratch as it started out as a game mainly for expatriates. Over the years, it grew to a local game that include both genders training and competing at local and international games, to organizing local games, to bidding of hosting of mega international competitions that were held in Singapore. These events were hard to imagine years back with little support and funding. The union has also progressed to develop talented youths into grooming them by organizing clinics and outreach programs in the local community. With constant improvements made, SRU aims to build on successful hosting events, create and maintain long-term marketing programmes to promote the sport internationally.

Moreover, to develope young talents and have long-term sustainability in the sport, it is essential for SportsSG and relevant government sectors to continue providing support, opportunities and funding to SRU. Hence, SRU can further 
provide additional support and opportunities to local schools and clubs in order to maintain or push the yardstick of rugby standards to greater heights. As sporting technology is continually evolving, constant coaching workshops are also made readily available to enhance the proficiency of these coaches, which coaches can implement during the players' training sessions. With a more advanced support system that involves more stakeholders, SRU is making steady progress in the sport to develop passionate and talented young local youths with the necessary skills to play well.

\section{REFERENCES}

1. Aplin, N. 2002. To the Finishing Line: Champions of Singapore Tang Pui Wah, Mary Klass, Janet Jesudason. Singapore: SNP International

2. Charles, L. 2013. 'Hamlet without the Prince': understanding Singapore Malaysian relations through football. Soccer \& Society. 14(5): 635-651

3. Godfrey, R. 2018. When we were kings: a golden era of Singapore Rugby. Epigram: Singapore.

4. Goh, D. 2014. Elite schools, postcolonial Chineseness and hegemonic masculinities in Singapore. British Journal of Sociology of Education. 36(1): 137155

5. Horton, P. 2012. Pacific Islanders in Global Rugby: The Changing Currents of Sports Migration. The International Journal of the History of Sports. 29(17), 2388-2404

6. Horton, P.A. 2007. "Padang or paddock": a comparative view of colonial sport in two imperial territories. The International Journal of the History of Sport. 14(1). $1-20$

7. Oon, D.S.W. 1984. Government Involvement in sport in Singapore 1959 - 1982 (PHD), University of Queensland, Brisbane, Australia

8. Singapore Rubgy Union (2020). History of Rugby in Singapore. (Adapted from https://www.singaporerugby.com/ourhistory/https://www.singaporerugby.com/our-history/)

9. Singapore Rugby Union. 2013. Standard Chartered Renews Commitment To Singapore Rugby Union Until 2016. https://www.singaporerugby.com/2013/09/25/standard-chartered-renewscommitment-to-singapore-rugby-union-until-2016/

10. Singapore Rugby Union. 2015. Mizuno Extends Official Footwear Sponsorship. https://www.singaporerugby.com/2015/12/09/mizuno-extends-officialfootwear-sponsorship/

11. Singapore Rugby Union. 2016a. Rhino Rugby Appointed As Official Training and Equipment Supplier to Singapore Rugby. https://www.singaporerugby.com/2016/01/18/rhino-rugby-appointed-asthe-official-training-and-equipment-supplier-to-singapore-rugby/

12. Singapore Rugby Union. 2016b. Rhino Rugby Asia's Offer to Singapore Rugby Community. https://www.singaporerugby.com/2016/01/20/rhino-rugbyasias-offer-to-singapore-rugby-community/ 
13. Singapore Sports Council. 2017. Sports in Colonial Times. https://www.sportsingapore.gov.sg/sports-education/history-of-singaporesports/sports-in-colonial-times

14. Singh, A. 2016. Rhino Rugby to Supply equipment for Singapore Rugby Union. TODAY Sports. https://www.todayonline.com/sports/rhino-rugby-supplyequipment-singapore-rugby-union

15. Tan, B. 2016. Singapore Cricket Club. Singapore Infopedia. https://eresources.nlb.gov.sg/infopedia/articles/SIP_144_2004-12-30.html

\section{ЗАРОЖДЕНИЕ И РАЗВИТИЕ РЕГБИ В СИНГАПУРЕ}

\section{АННОТАЦИЯ}

В далекие времена некоторые виды спорта были разновидностью других видов спорта. Регби было одним из видов спорта, который представлял собой разновидность футбола. Кодификация правил регби произошла только в середине 18 века, и поэтому команды участников игр в регби представляли собой смешение игроков из других видов спорта, таких как теннис и крикет. Кроме того, не существовало официальной ассоциации регби или игроков, представляющих Сингапур. Игроки, выступавшие за Сингапур, были членами SCC и служащими BEIC. В те времена они соревновались в турнирах с командами малайских штатов и с другими командами.

Ключевые слова: регби, игры, мяч

Reccived on 22.04.2020.

Accepted on 21.05.2020. 